\title{
NEW DISTRIBUTIONAL DATA ON BRYOPHYTES OF POLAND AND SLOVAKIA, 13
}

\author{
Piotr Górski, Grzegorz Vončina, Ewa Fudali, Ludwik ŻoŁNierz \\ Series "New distributional data on bryophytes \\ of Poland (and Slovakia)" is a scientific bulletin \\ of Bryological Section of Polish Botanical Society

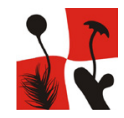

\author{
Editors of the column: Piotr GóRsKi, ANNA RusińsKa
}

\begin{abstract}
E. Fudali, Department of Botany and Plant Ecology, Wrocław University of Environmental and Life Sciences, pl. Grunwaldzki 24 A, 50-363 Wrocław, Poland, e-mail: ewa.fudali@gmail.com

P. Górski, Department of Botany, Poznań University of Life Sciences, Wojska Polskiego 71 C, 60-625 Poznań, Poland, e-mail: piotr.gorski@up.poznan.pl

A. Rusińska, Natural History Collections, Adam Mickiewicz University, Umultowska 89, 61-614 Poznań, Poland, e-mail: annarus@amu.edu.pl

G. Vončina, Pieniny National Park, Jagiellońska 107 B, 34-450 Krościenko nad Dunajcem, Poland, e-mail: gvoncina@ poczta.onet.pl

L. Żołnierz, Department of Botany and Plant Ecology, Wrocław University of Environmental and Life Sciences, pl. Grunwaldzki 24 A, 50-363 Wrocław, Poland, e-mail: ludwik.zolnierz@upwr.edu.pl
\end{abstract}

(Received: January 18, 2018. Accepted: February 20, 2018)

AвSTRACT. This work presents a list of localities for the following species: Didymodon fallax var. brevifolius, Fissidens exilis, Nowellia curvifolia, Orthocaulis atlanticus, Orthotrichum lyellii, Ptilium crista-castrensis, and Syntrichia virescens.

1. Didymodon fallax (Hedw.) R.H. Zander var. brevifolius (Dicks.) Ochyra

Author: G. VončinA

ATMOS Gf-21: S Poland, Beskid Niski Range, Podkarpacie Province, Jasło county, Nowy Żmigród commune, not exist Hałbów village near Desznica, Magurski National Park, on the sandstone in the bed of the righthand tributary of Ryj stream, in the silver fir forest, alt. $467 \mathrm{~m}$ above sea level (a.s.l.), $49.53736^{\circ} \mathrm{N}, 21.49364^{\circ} \mathrm{E}, \quad$ leg., det. G. Vončina, 7.05.2016 (SOSN); ATMOS Fd-58: S Poland, Wyżyna Śląsko-Krakowska Upland, Małopolska Province, Kraków county, Wielka Wieś commune, Duże Skałki (Wapiennik), on the clay soil in the limestone quarry, alt. $451 \mathrm{~m}$ a.s.l., $50.18983^{\circ} \mathrm{N}, 19.80625^{\circ} \mathrm{E}$, leg., det. G. Vončina, 1.10.2017 (SOSN).
Didymodon fallax var. brevifolius is a rare taxon in Poland (SZAFran 1957). The most recent record from the Polish lowlands was located in the Pojezierze Gnieźnieńskie Lakeland in Wapienno (RusińsKa \& RosADZIŃsKI 2010). The species was also observed in the Polish uplands on the Pagóry Chełmskie Hills (LisowsKi 1959a). In the Western Carpathians it is considered as rare or very rare (StEBel 2006). The first Carpathian records were derived from the north-facing slopes of the Tatra Mountains (CHAŁUBIŃsKi 1886), and the Pogórze Wielickie Foothills (ŻMUDA 1912). The next records were from the Pieniny Range (OcнYRa 1984, Stebel et al. 2010, Vončina \& Stebel 2016) and the Pogórze Orawsko-Jordanowskie Foothills (Stebel \& Vončina 2014). Records from the Sudety Mountains refer to the Góry Kaczawskie Mountains (LisowsKi 1956a, WILCZYŃSKA 1974). 
Didymodon fallax var. brevifolius is a threadlike moss with short leaves measuring up to $1 \mathrm{~mm}$ that grows on rocks (sandstones, limestones) and eroded wayside slopes. This taxon is most frequent in the mountains, and outside mountain areas, in quarries. The described stations are the first records from Magurski National Park in the Beskid Niski Range and the Wyżyna Śląsko-Krakowska Upland.

\section{Fissidens exilis Hedw.}

Author: G. VončinA

ATMOS Ge-33: S Poland, Pieniny Range, Małopolska Province, Nowy Targ county, Krościenko nad Dunajcem commune, Krościenko nad Dunajcem village, between Stolarzówka and Bańków Gronik glades, Pieniński National Park, on the clay wayside in the silver fir Abies alba forest, alt. $650 \mathrm{~m}$ a.s.1., $49.42764^{\circ} \mathrm{N}$, $20.41592^{\circ} \mathrm{E}$, leg., det. G. Vončina, 13.10.2011 (SOSN); ATMOS Gf-22: S Poland, Beskid Niski Range, Podkarpacie Province, Krosno county, Dukla commune, Nowa Wieś village, nearby national road No. 19, on the sandy soil on the roadside, ca alt. $350 \mathrm{~m}$ a.s.l., leg. J. Sieradzki, 2013, det. M. Staniaszek-Kik (LOD).

In the western part of the Polish Carpathians Fissidens exilis is either rare or not confirmed in recent years (SZAFRAN 1952, 1954, WACŁAWSKA 1957, SteBEL 2003, 2004, 2006, 2008, 2010, Stebel et al. 2010). The situation is similar in the eastern part of the Carpathians (ARMATA 2005) and in south-western Poland where the species was noted only in the Góry Kaczawskie Mountains (WILCZYŃsKa 1974). The first information about the occurrence of the species in the Pieniny Range was provided by SzAFRAN (1952). Following that, F. exilis was not observed in the Pieniny Range until a study in the Małe Pieniny Range (Ochyra \& Stebel 2008). The first information from the Beskid Niski Range was published by WaCŁAWSKA (1957) with no further reports since then.

Fissidens exilis occurs in the northern (Pojezierze Mazurskie and Pojezierze Pomorskie Lakelands) and southern part of Poland (Lower and Upper Silesia, Pieniny Range), but has not been found in the middle of Poland (SZAFran 1957). It grows on bare loam or clay soil along river banks or waysides. The described locality is the second (beside Ochyra \& Stebel 2008) record from the Pieniński National Park in 60 years.

\section{Nowellia curvifolia (Dicks.) Mitt.}

Author: P. GóRSKI

SLOVAKIA: MGRS 34UDV0757, Western Tatra Mts, Skupina Osobitej-Bobrovca, Suchá dolina valley, lower part of Široký žlab gully, decaying log, $49.26642^{\circ} \mathrm{N}$, $19.73153^{\circ} \mathrm{E}$, alt. $1135 \mathrm{~m}$ a.s.l., leg., det. P. Górski, 24.09.2015 (POZNB 2064); MGRS 34UDV0843, Western Tatra Mts, Masív Baranca a Rázsochy, lower part of Trnovská dolina valley, decaying log near stream, $49.13597^{\circ} \mathrm{N}, 19.74236^{\circ} \mathrm{E}$, alt. $895 \mathrm{~m}$ a.s.l., leg., det. P. Górski, 19.09.2015 (POZNB 2353); MGRS 34UDV1949, Western Tatra Mts, Tomanovsko-jamnické vrchy, Dolina Hlina valley, at the mouth of Široký žlab gully, decaying log near Hlina stream, $49.19157^{\circ} \mathrm{N}, 19.89894^{\circ} \mathrm{E}$, alt. $1325 \mathrm{~m}$, leg., det. P. Górski, 24.10.2017 (POZNB 2515); MGRS 34UDV2546, High Tatra Mts, Skupina Kriváňa, at the mouth of Krivánska kotlina basin, blocks of rock in dwarf mountain pine, $49.16927^{\circ} \mathrm{N}, 19.98352^{\circ} \mathrm{E}$, alt. $1498 \mathrm{~m}$ a.s.l., not. P. Górski, 10.08.2017; MGRS 34UDV2547, High Tatra Mts, Skupina Kriváňa, Kôprová dolina valley, Niedźwiedzia perć path, at the mouth of Krivánska kotlina basin, south from Nefcerský potok stream, $49.17195^{\circ} \mathrm{N}, 19.98372^{\circ} \mathrm{E}$, alt. $1435 \mathrm{~m}$ a.s.l., leg., det. P. Górski, 16.09.2015 (POZNB 2399); MGRS 34UDV2647, High Tatra Mts, Skupina Kriváňa, Kôprová dolina valley, Niedźwiedzia perć path, at the mouth of Krivánska kotlina basin, near Nefcerský potok stream, $49.17437^{\circ} \mathrm{N}, 19.98525^{\circ} \mathrm{E}$, alt. 1350 $\mathrm{m}$ a.s.l., $49.17388^{\circ} \mathrm{N}, 19.98491^{\circ} \mathrm{E}$, alt. $1360 \mathrm{~m}$ a.s.l., leg., det. P. Górski, 16.09.2015 (POZNB 2384, 2392); MGRS 34UDV3753, High Tatra Mts, Skupina Širokej, lower part of the Svištovská dolina valley, decaying log in spruce forest, $49.22892^{\circ} \mathrm{N}, 20.14034^{\circ} \mathrm{E}$, alt. 1350 $\mathrm{m}$ a.s.l., leg., det. P. Górski, 6.11.2015 (POZNB 1993); 34UDV4754, Belianske Tatra Mts, Východné Belianske Tatry, Babia dolina valley (upper part of Babilovská dolina valley), decaying log near stream, $49.24363^{\circ} \mathrm{N}$, $20.27266^{\circ} \mathrm{E}$, alt. $1060 \mathrm{~m}$ a.s.l., leg., det. P. Górski, 29.07.2016 (POZNB 2303); MGRS 34UDV4755, Belianske Tatra Mts, Východné Belianske Tatry, Babia dolina valley (upper part of Babilovská dolina valley), decaying $\log , 49.24766^{\circ} \mathrm{N}, 20.27452^{\circ} \mathrm{E}$, alt. $970 \mathrm{~m}$ a.s.l., leg., det. P. Górski, 28.07.2016 (POZNB 2234); Poland: MGRS 34UDV3452, ATMOS Ge-51, High Tatra Mts, Wierchy Pięciostawiańsko-Białczańskie, Dolina Rybiego Potoku valley, spruce forest near junction of the Rybi Potok stream with the Białka stream, alt. 1110 m a.s.l., leg., det. P. Górski, 6.08.2013 (POZNB 2253).

In the entire area of the Tatra Mountains, 67 localities (55 from Slovakia, 12 from Poland) of Nowellia curvifolia have been recorded within an altitude range of 800-1650 m a.s.l. (GóRSKI \& VÁŇA 2014). This report presents another 11 localities for this plant in this massive.

\section{Orthocaulis atlanticus (Kaal.) H. Buch [= Barbilophozia atlantica (Kaal.) Müll. Frib.]}

Author: P. GóRsKI

SlovakiA, High Tatra Mts, 34UDV3652, Skupina Širokej, Svištovská dolina valley, Vaccinietum myrtil$l i$, on humus in dwarf mountain pine, $49.22435^{\circ} \mathrm{N}$, $20.13148^{\circ} \mathrm{E}$, alt. $1535 \mathrm{~m}$ a.s.l., leg., det. P. Górski, 9.11.2015 (POZNB 1987, KRAM); Poland, High Tatra Mts: MGRS 34UDV3054, ATMOS Ge-50, 
Masyw Waksmundzki, Koszysta ridge, SW from Mt Mała Koszysta, $49.24340^{\circ} \mathrm{N}, 20.05154^{\circ} \mathrm{E}$, alt. 2020 $\mathrm{m}$ a.s.l., $49.24291^{\circ} \mathrm{N}, 20.05058^{\circ} \mathrm{E}$, alt. $2035 \mathrm{~m}$ a.s.l., leg., det. P. Górski, 30.07.2016 (POZNB 2176, 2308); MGRS 34UDV3155, ATMOS Ge-50, Masyw Waksmundzki, Koszysta ridge, NE from Mt Mała Koszysta, rocky ledge with Polytrichum alpinum, $49.24484^{\circ} \mathrm{N}$, $20.05500^{\circ} \mathrm{E}$, alt. $1950 \mathrm{~m}$ a.s.l., leg., det. P. Górski, 30.07.2016 (POZNB 2177).

Orthocaulis atlanticus is a high-alpine, rare liverwort reported in Poland from the Tatra Mountains (SZWEYKOWSKI 1956, 1960, 1967, BALCERKIEWICZ 1984, CYKOWSKA 2011, GÓRSKI \& VÁŇA 2014), and recently (from one locality) in the Karkonosze Mountains, Sudety Mts (GóRSKI \& PRZEWOźNIK in GóRsKI et al. 2014). In Slovakia, this species is known only in the Tatra Mts at two localities (Duda 1983, Duda \& VÁŇA 1984, GóRSKI \& VÁŇA 2014) and is considered critically endangered (CR, KUBINSKÁ et al. 2001). In the entire Tatra Mountains (including new data presented here), 31 localities of $O$. atlanticus have been recorded within an altitude range of $1535-2220 \mathrm{~m}$ a.s.l. One of the three new sites is a new minimum (at $1535 \mathrm{~m}$ a.s.l.) for this species in the Tatra Mts.

\section{Orthotrichum lyellii Hook. \& Taylor}

Author: G. VonČINA

ATMOS Ge-29: S Poland, Beskid Niski Range, Małopolska Province, Gorlice county, Sękowa commune, Krzywe village, Banica hamlet, lefthand tributary of Jasionka stream, on the Salix fragilis bark in the grove along the stream bank, alt. $560 \mathrm{~m}$ a.s.l., $49.52578^{\circ} \mathrm{N}, 21.31283^{\circ} \mathrm{E}$, leg., det. G. Vončina, 17.04.2016 (SOSN); ATMOS Gf-18: S Poland, Góry Sanocko-Turczańskie Range, Podkarpackie Province, Bieszczady county, Ustrzyki Dolne commune, Nowosielce Kozickie village, the grove of Fraxinus excelsior near the church, on the ash bark, alt. $439 \mathrm{~m}$ a.s.l., $49.56281^{\circ} \mathrm{N}, 22.52956^{\circ} \mathrm{E}$, leg., det. G. Vončina, 30.04.2016 (SOSN), accompanying species: Leucodon sciuroides; ATMOS Gf-27: S Poland, Góry Sanocko-Turczańskie Range, Podkarpackie Province, Lesko county, Olszanica commune, Rudenka village, Słonne forest, near the Dyrbek stream, on the Acer pseudoplatanus bark in the Carpathian beech forest Dentario glandulosae-Fagetum, alt. $523 \mathrm{~m}$ a.s.l., $49.51108^{\circ} \mathrm{N}, 22.42833^{\circ} \mathrm{E}$, leg., det. G. Vončina, 1.05.2016 (SOSN); ATMOS Gf-27: S Poland, Góry Sanocko-Turczańskie Range, Podkarpackie Province, Lesko county, Olszanica commune, Wańkowa village, Stop hill, on the Acer pseudoplatanus bark in the Carpathian silver fir forest Dentario glandulosaeFagetum abietetosum, alt. $506 \mathrm{~m}$ a.s.1., $49.52328^{\circ} \mathrm{N}$, $22.45011^{\circ} \mathrm{E}$, leg., det. G. Vončina, 1.05.2016 (SOSN).

Orthotrichum lyellii is a partially protected species under Polish law (RozPoRzĄDZENIE... 2014) at present and from 2004 to 2014 it was a strictly protected plant in Poland (Rozporządenie... 2004). This epiphytic moss occurs throughout Poland (SZAFran 1961), but is a threatened species. In the current Red-list it is treated as a rare species in Poland (category R) and a vulnerable species in the Carpathians (category $\mathrm{V}$ ) (ŻARNowiec et al. 2004). In the Polish Carpathians the species occurs most frequently in the Bieszczady, Beskid Śląski and Beskid Żywiecki Ranges, and in other parts of the Carpathians it is found at scattered localities (Stebel 2011). In recent years the moss has been found in the Roztocze (Fudali et al. 2015), Góry Sanocko-Turczańskie Mts (SteBel et al. 2016, FojcIK et al. 2017) and Przemyśl Foothills (StANIASZEK-KIK et al. 2017).

The described locality from the Beskid Niski Range is the second record from this region (beside Stebel 2011). The rest of the newly recorded stations provide additional data to the one published locality from the Góry Sanocko-Turczańskie Mountains.

\section{Ptilium crista-castrensis (Hedw.) De Not.}

Author: G. VonČINA

ATMOS Gf-21: S Poland, Beskid Niski Range, Podkarpacie Province, Jasło county, Nowy Żmigród commune, not exist Hałbów village near Desznica, Magurski National Park, $49.53514^{\circ} \mathrm{N}, 21.49403^{\circ} \mathrm{E}$, on the rotting log of silver fir Abies alba, in the bed of the righthand tributary of the Ryj stream, alt. $499 \mathrm{~m}$ a.s.1., leg., det. G. Vončina, 7.05.2016 (SOSN).

Ptilium crista-castrensis is a partially protected species under Polish law (Rozporządzenie... 2014). This species occurs throughout Poland and is considered as a relatively frequent moss (SZAFRAN 1961), although in the mountain regions it has been recorded relatively rarely. In the western part of the Polish Carpathians this species is very rare or not confirmed in recent years (Ochyra 1984, Stebel 2006, 2008, Ochyra \& Stebel 2008, Stebel et al. 2010, Stebel \& VončiNA 2014). The information from the Polish foothills and the eastern part of the Western Carpathians is also very exclusive (KarczMARz 1987, ARMATA 2006). The situation is similar in the Beskidy Wschodnie Range where the species was recorded only a few times in Bieszczady (Lisowski 1956b) and in the Góry Sanocko-Turczańskie Mts (Stebel et al. 2016). In the Tatra Mts Ptilium crista-castrensis was observed at a few scattered stations (LIsowski 1959b). Unlike in the Carpathians, information about the frequent occurrence of moss in the Wyżyna Krakowsko-Częstochowska Upland was presented by Fолсік (2011). The remaining reports from Poland are scarce, although in the last two decades there has been more information about new stations of this species in Poland (Ciosek \& Trzpil-Zwierzyk 2003, Wolski \& Fudali 2013, Fudali et al. 2015, WiLHelm et al. 2015).

Ptilium crista-castrensis usually grows on the ground in coniferous forests, in Carpinion betuli forest and on 
rotting wood, generally in small scattered patches and sometimes in larger expanses. Only a few stems of moss are growing at the described locality. The described station is the first record from Magurski National Park and the second observation in the Beskid Niski Range (beside Stebel 2011).

\section{Syntrichia virescens (De Not.) Ochyra}

Authors: E. FudALI, L. ŻoenIeRZ

ATMOS Eb-48: SW Poland, Silesian Lowland (Nizina Śląska), Wrocław Valley (Pradolina Wrocławska), area of the Wrocław town, edge of urban forest situated in NW suburbs (Las Rędziński Forest), $51.178008^{\circ} \mathrm{N}, 16.932786^{\circ} \mathrm{E}$, bark of Populus nigra in humid riverside forest, leg., det. E. Fudali, L. Żołnierz, 3.10.2015 (KRAM); settlement Maślice in NW suburbs, $51.157299^{\circ} \mathrm{N}, 16.929418^{\circ} \mathrm{E}$, trunks of Tilia platyphyllos and Fraxinus excelsior along the Maślicka street, leg., det. E. Fudali, 21.08.2014 (herb. E. Fudali); settlement Pracze Odrzańskie in NW suburbs, $51.174863^{\circ} \mathrm{N}, 16.907134^{\circ} \mathrm{E}$, trunk of Fraxinus excelsior along the Brodzka street, leg., det. E. Fudali, 4.07.2014 (KRAM); built-up area of the Wrocław town: settlement Popowice, $51.126004^{\circ} \mathrm{N}, 17.006890^{\circ} \mathrm{E}$, trunk of Populus canadensis along the side street, trunks of Robinia pseudoacaccia in forested square among buildings, leg., det. E. Fudali, 30.07.2013 (herb. E. Fudali); settlement Szczepin, $51.119013^{\circ} \mathrm{N}, 16.992281^{\circ} \mathrm{E}$, trunks of Acer negundo, A. platanoides and Populus nigra var. italica on small green square among streets, leg., det. E. Fudali, 16.07.2013 (KRAM); ATMOS Eb-49: SW Poland, Silesian Lowland, Wrocław Valley, built-up area of the Wrocław town, Old Town in the city center, park along city moat, $51.107593^{\circ} \mathrm{N}$, $17.023083^{\circ} \mathrm{E}$, trunk of Acer platanoides, $51.114206^{\circ} \mathrm{N}$, $17.039954^{\circ}$ E, trunk of Populus nigra, leg., det. E. Fudali, 17.07.2013 (KRAM); Down Town, close to Most Grunwaldzki bridge, $51.109515^{\circ} \mathrm{N}, 17.051035^{\circ} \mathrm{E}$, trunks of Populus $\times$ berolinensis on small green square, leg., det. E. Fudali, 10.05.2015 (herb. E. Fudali); Down Town, Sienkiewicza street, $51.16337^{\circ} \mathrm{N}$, $17.059889^{\circ} \mathrm{E}$, trunk of old specimen of Populus nigra situated on inner courtyard among old tenement houses, leg., det. E. Fudali, 10.09.2014 (KRAM); settlement Karłowice, $51.16337^{\circ} \mathrm{N}, 17.059889^{\circ} \mathrm{E}$, trunk of Ulmus laevis in green belt around the school, leg., det. E. Fudali, 21.07.2015 (herb. E. Fudali); settlement Biskupin, $51.16337^{\circ} \mathrm{N}, \quad 17.059889^{\circ} \mathrm{E}$, trunks of Populus $\times$ canadensis and Fraxinus excelsior along the street, leg., det. E. Fudali, 6.10.2013 (herb. E. Fudali); settlement Sępolno, sport stadium, $51.120431^{\circ} \mathrm{N}, 17.091163^{\circ} \mathrm{E}$, trunks of Acer platanoides and Populus $\times$ canadensis along the street, leg., det. E. Fudali, 17.06.2014 (KRAM); settlement Psie Pole, $51.148725^{\circ} \mathrm{N}, 17.118590^{\circ} \mathrm{E}$, trunks of Robinia pseudoacaccia and Fraxinus excelsior on small square next to the street, leg., det. E. Fudali, 12.08.2014 (herb. E. Fudali); settlement Rakowiec in E suburbs, $51.094796^{\circ} \mathrm{N}, 17.062203^{\circ} \mathrm{E}$, trunk of Populus nigra on riverside, leg., det. E. Fudali, L. Żołnierz, 5.10.2015 (KRAM); ATMOS Eb-58: SW Poland, Silesian Lowland, Wrocław Valley, built-up area of the Wrocław town, settlement Grabiszyn, $51.090610^{\circ} \mathrm{N}$, $16.976714^{\circ} \mathrm{E}$, trunk of Acer negundo in green belt along the street, leg., det. E. Fudali, 1.08.2013 (herb. E. Fudali); settlement Oporów, $51.077856^{\circ} \mathrm{N}$, $16.965805^{\circ} \mathrm{E}$, trunk of Quercus robur next to the street, leg., det. E. Fudali, 14.10.2013 (KRAM); ATMOS Eb-59: SW Poland, Silesian Lowland, Wrocław Valley, built-up area of the Wrocław town, settlement Borek, $51.089771^{\circ} \mathrm{N}, 17.031008^{\circ} \mathrm{E}$, trunk of Populus $\times$ canadensis in green square next to the street, leg., det. E. Fudali, 18.08.2015 (herb. E. Fudali); settlement Huby, $51.093430^{\circ} \mathrm{N}, 17.032260^{\circ} \mathrm{E}$, trunk of Populus $\times$ canadensis in green square next to the street, leg., det. E. Fudali, 21.08.2015 (KRAM); settlement Krzyki, $51.094996^{\circ} \mathrm{N}, 17.022193^{\circ} \mathrm{E}$, trunks of Populus $\times$ canadensis and Acer platanoides in green square next to the street, leg., det. E. Fudali, 21.08.2015 (herb. E. Fudali); ATMOS Ec-40: SW Poland, Silesian Lowland, Wrocław Valley, NE suburbs of the Wrocław town, settlement Zakrzów, $51.153337^{\circ} \mathrm{N}$, $17.125540^{\circ} \mathrm{E}$, bark of Acer platanoides at the street, leg., det. E. Fudali, L. Żołnierz, 27.10.2015 (KRAM).

Syntrichia virescens is listed as a partly protected moss in Poland (RozPoRZĄDZENIE... 2014). ŻARNOWIEC et al. (2004) considered it a rare species ( $R$ category) that occurs in small populations and is not at present endangered or vulnerable but is at risk. This epiphytic moss species is distributed throughout the country but it is not frequent anywhere. In the past ( $19^{\text {th }}$ century) S. virescens was reported from the around Wrocław (MiLDE 1869) but it was not observed in Wrocław or in its surroundings during the $20^{\text {th }}$ century (WilcZYŃSKA \& KoŁA 1974-1975a, b, FuDALI 1988). The first contemporaneous report dates from 2006 (Fudali 2007). At all reported stations $S$. virescens occurred in very small clumps $\left(1-4 \mathrm{~cm}^{2}\right)$ and was collected at a height of 0.8 to $1.2 \mathrm{~m}$ above the ground.

\section{ACKNOWLEDGEMENTS}

The contribution by Piotr Górski was supported by the Ministry of Science and Higher Education, Warsaw, Poland (statuory funds No 508.641.01).

\section{REFERENCES}

Armata L. (2005): A contribution to the bryoflora of the Pogórze Dynowskie Foothills (Western Carpathians). Annales Universitatis Mariae Curie-Skłodowska, Sectio C 60: 101-111.

ARmata L. (2006): New records of rare and endangered mosses from the Bieszczady Zachodnie 
Range and the Carpathian Foothills. Annales Universitatis Mariae Curie-Skłodowska, Sectio C 61(7): 131-139.

BALCERKIEWICZ S. (1984): Roślinność wysokogórska Doliny Pięciu Stawów Polskich w Tatrach i jej przemiany antropogeniczne. Uniwersytet im. Adama Mickiewicza, Seria Biologia 25: 1-191.

ChAŁUBiŃsKi T. (1886): Enumeratio muscorum frondosorum tatrensium, hucusque cognitorum. Pamiętnik Fizyjograficzny Dział 3 (Botanika i Zoologija) 6: I-VIII + 1-207.

Ciosek M.T., TrzPil-ZwierzyK B. (2003): Ptilium crista-castrensis w Polsce środkowowschodniej a występowanie innych gatunków borealnych. Acta Scientiarum Polonorum, Biologia 2(1-2): 43-49.

Сүкошsка В. (2011): Bryophytes of Sphagnum-Polytrichum hummocks in the Polish Tatra Mountains. In: A. Stebel, R. Ochyra (eds). Chorological studies on Polish Carpathian bryophytes. Sorus, Poznań: 233-259.

DudA J. (1983): Barbilophozia atlantica in der Tschechoslovakei (Hepaticae). Preslia 55(3): 265-267.

DudA J., VÁŇA J. (1984): Rozšíření játrovek v Československu - XLI. Časopis Slezského Muzea, Series A, Opava 33: 217-232.

Fojcik B. (2011). Mchy Wyżyny Krakowsko-Częstochowskiej w obliczu antropogenicznych przemian szaty roślinnej. Wydawnictwo Uniwersytetu Śląskiego, Katowice.

Fojcik B., Stebel A., Zubel R., Staniaszek-Kik M., Vončina G., RusińsKa A., Szczepański M. (2018): Brioflora rezerwatu Na Opalonym w Górach Sanocko-Turczańskich (Karpaty Wschodnie). Parki Narodowe i Rezerwaty Przyrody 37(1): 3-19.

FudALI E. (1988): Investigations of bryophytes in Polish towns - a review of the bryological research and data. Fragmenta Floristica et Geobotanica 43(1): 77-101.

FudAli E. (2007): Tendencje dynamiczne w brioflorze miejskich parków - na przykładzie Wrocławia. Annales Silesiae 35: 11-20.

Fudali E., Zubel R., Stebel A., Rusińska A., Górski P., Vončina G., Rosadziński S., CYkowska B., Staniaszek-Kik M., Wierzcholska S., Wolski G.J., Wojterska M., Wilhelm M., Paciorek T., Piwowarski B. (2015): Contribution to the bryoflora of Roztocze National Park (SE Poland). Bryophytes of the Świerszcz river valley. Steciana 19(1): 39-54.

Górski P., PaWlikowski P., Staniaszek-KIK M., Rosadziński S., Stebel A., Rusińska A., Zubel R., Wilhelm M., Fudali E., Cykowska-Marzencka B., PrZewoźNIK L. (2014): New distributional data on bryophytes of Poland, 1. Steciana 18(2): 77-87.

GÓRSKI P., VÁŇA J. (2014): A synopsis of liverworts occurring in the Tatra Mountains (Western Carpathians, Poland and Slovakia): checklist, distribution and new data. Preslia 86(4): 381-485.
Karczmarz K. (1987): Flora mszaków Beskidu Niskiego. Annales Universitatis Mariae Curie-Skłodowska, Sectio C 42(10): 111-135.

KubinsKÁ A., Janovicová K., Šoltés R. (2001): Aktualizovaný zoznam pečeňoviek, rožtekov a machov Slovenska. Bryonora 28: 4-10.

Lisowski S. (1956a): Bryotheca Polonica. Fasc. 5. No. 151-175. Musci in montibus "Góry Kaczawskie” collecti. Academia Scientiarum Poloniae, Posnaniae.

Lisowski S. (1956b): Mchy Bieszczadów Zachodnich. Prace Komisji Biologicznej Poznańskiego Towarzystwa Przyjaciół Nauk 17(3): 1-95.

Lisowski S. (1959a): Bryotheca Polonica. Fasc. 47. No. 1201-1225. Musci Regionis Lublinensis (pars septentrionali-orientalis). Academia Scientiarum Poloniae, Posnaniae.

Lisowski S. (1959b): Materiały do bryoflory Tatr. Prace Komisji Biologicznej Poznańskiego Towarzystwa Przyjaciół Nauk 21(2): 1-129.

MiLDE J. (1869): Bryologia Silesiaca, Laubmoos-Flora von Nord- und Mittel-Deutschland, unter besonderer Berücksichtigung Schlesiens und mit Hinzunahme der Floren von Jütland, Holland, der Rheinpfalz, von Baden, Franken, Böhmen, Mähren und der Umgegend von München. Verlag von Arthur Felix, Leipzig.

OchYra R. (1984): Mchy Skalic Nowotarskich i Spiskich (Pieniński Pas Skałkowy). Fragmenta Floristica et Geobotanica 28(3): 419-489.

Ochyra R., Stebel A. (2008): Mosses of the Małe Pieniny Range (Polish Western Carpathians). In: A. Stebel, R. Ochyra (eds). Bryophytes of the Polish Carpathians. Sorus, Poznań: 75-141.

RozPORZĄDZENIE Ministra Środowiska z dnia 9 lipca 2004 r. w sprawie gatunków dziko występujących roślin objętych ochroną. (2004). Dziennik Ustaw nr 168, poz. 1764.

RozPORZĄDZENIE Ministra Środowiska z dnia 9 października 2014 r. w sprawie ochrony gatunkowej roślin. (2014). Dziennik Ustaw Rzeczypospolitej Polskiej z 16 października 2014 roku, poz. 1409.

RusińsKa A., RosAdzińsKi S. (2010): Mszaki. In: J. Drążek, J. Chmiel, M. Knapczyk, A. Rusińska (eds). Krajobrazy pałuckich wapieni. 150 lat białego górnictwa. Stowarzyszenie Ekologiczne, Barcin: 67-79.

Staniaszek-Kik M., Zubel R., Fudali E., Rusińska A., Fojcik B., Vončina G., Stebel A., Szczepański M. (2017): A contribution to the moss and liverwort flora of the Reberce nature reserve at the Przemyśl Foothills (Western Carpathians, Poland). Steciana 21(1): 7-15.

Stebel A. (2003): Mszaki rezerwatów przyrody Morzyk i Skarpa Wiślicka na Pogórzu Śląskim. Archiwum Ochrony Środowiska 29(1): 99-110.

Stebel A. (2004): A contribution to the bryoflora of the Western part of the Carpathian Foothills. 
In: A. Stebel, R. Ochyra (eds). Bryological studies in the Western Carpathians. Sorus, Poznan: $135-145$.

Stebel A. (2006): The mosses of the Beskidy Zachodnie as a paradigm of biological and environmental changes in the flora of the Polish Western Carpathians. Medical University of Silesia in Katowice, Sorus, Katowice, Poznań.

Stebel A. (2008): Mosses of the Kotlina Żywiecka Basin (Western Carpathians). In: A. Stebel, R. Ochyra (eds). Bryophytes of the Polish Carpathians. Sorus, Poznań: 11-74.

Stebel A. (2010): Mosses of the Beskid Mały Range (Western Carpathians). Materiały Opracowania, Centrum Dziedzictwa Górnego Śląska 11: 1-142.

Stebel A. (2011): Distribution of Orthotrichum lyellii (Bryophyta, Orthotrichaceae) in the Polish Carpathians. In: A. Stebel, R. Ochyra (eds). Chorological studies on Polish bryophytes. Sorus, Poznań: 111-120.

Stebel A., Ochyra R., Vončina G. (2010): Mosses of the Pieniny Range (Polish Western Carpathians). Sorus, Poznań.

Stebel A., Vončina G. (2014): Bryophyte diversity in the flora of the Orawsko-Jordanowskie Foothills (Polish Western Carpathians). Muzeum Tatrzańskie, Zakopane.

Stebel A., Zubel R., Vončina G., Fudali E., WierzCHOlsKa S., StaniasZek-Kik M., Fojcik B., RusińSKa A., Szczepański M. (2016): Różnorodność gatunkowa mszaków rezerwatu leśnego Chwaniów (Góry Sanocko-Turczańskie, Karpaty Wschodnie). Acta Botanica Silesiaca 12: 85-100.

Szafran B. (1952): Mchy Pienin. Ochrona Przyrody 20: 89-117.

SZAFRAN B. (1954): Zapiski bryologiczne z Karpat Zachodnich (Beskidy, Tatry, Pieniny). Fragmenta Floristica et Geobotanica 2(1): 143-167.

SzAFran B. (1957): Mchy (Musci). 1. Państwowe Wydawnictwo Naukowe, Warszawa.

Szafran B. (1961): Mchy (Musci). 2. Państwowe Wydawnictwo Naukowe, Warszawa.

SzWEYKowsKi J. (1956): Ważniejsze znaleziska wątrobowców w latach 1955 i 1956. Sprawozdania Poznańskiego Towarzystwa Przyjaciół Nauk, Poznań 46: 118-119.

SzWEYKOWSKI J. (1960): Materiały do flory wątrobowców Tatr. Prace Komisji Biologicznej Poznańskiego Towarzystwa Przyjaciół Nauk 21(3): 3-92.

SzWEYKOWsKi J. (1967): H. 78. Orthocaulis atlanticus (Kaalaas) Buch. In: Z. Czubiński, J. Szweykowski (eds.). Atlas of geographical distribution of spore plants in Poland. Vol. 4. Series 4. Liverworts (Hepaticae). Polska Akademia Nauk, Poznańskie Towarzystwo Przyjaciół Nauk, Poznań.

Vončina G., Stebel A. (2016): Materiały do flory mchów Pienińskiego Pasa Skałkowego (Karpaty Zachodnie). Pieniny - Przyroda i Człowiek 14: 79-89.

WaCŁAWSKa Z. (1957): Mchy dorzecza górnego Wisłoku. Fragmenta Floristica et Geobotanica 3(1): 93-113.

WiLCZYŃSKA W. (1974): Flora mchów i zbiorowisk mszaków Gór Kaczawskich. Studium florystyczno-ekologiczne. Monographiae Botanicae 44: $1-122$.

WiLCZYŃSKA W., KoŁA W. (1974-1975a): Flora i zbiorowiska mszaków rezerwatu Muszkowicki Las Bukowy w woj. wrocławskim. Opolskie Towarzystwo Przyjaciół Nauk, Zeszyty Przyrodnicze 14-15: 65-86.

WiLCZYŃSKA W., KoŁA W. (1974-1975b): Mszaki rezerwatów jodłowych Wzgórz Trzebnicko-Ostrzeszowskich. Opolskie Towarzystwo Przyjaciół Nauk, Zeszyty Przyrodnicze 14-15: 87-107.

Wilhelm M., Rusińska A., Stebel A., Górski P., Vončina G., Fojcik B., Rosadziński S., Fudali E., Salachna A., ZuBel R. (2015): Contribution to the bryoflora of the Wolin island (NW Poland). Steciana 19(2): $75-87$.

Wolski G.J., Fudali E. (2013): Species and ecological diversity of bryophytes occurring on midforest roads in some forest nature reserves in Central Poland. Steciana 17: 141-148.

Żarnowiec J., Stebel A., Ochyra R. (2004): Threatened moss species in the Polish Carpathians in the light of a new red-list of mosses in Poland. In: A. Stebel, R. Ochyra (eds). Bryological studies in the Western Carpathians. Sorus, Poznań: 9-28.

ŻMUDA A. (1912): Zapiski bryologiczne $z$ powiatu wielickiego. Kosmos (Lwów) 37: 109-117.

For citation (1): GóRSKI P., VONČINA G., FudALI E., ŻoŁNIERZ L. (2018): New distributional data on bryophytes of Poland and Slovakia, 13. Steciana 22(1): 13-18. doi:10.12657/steciana.022.001.

For citation (2): Fudali E., ŻotNierz L. (2018): 7. Syntrichia virescens (De Not.) Ochyra. In: Górski P., Rusińska A. (eds). New distributional data on bryophytes of Poland and Slovakia, 13. Steciana 22(1): 16. doi:10.12657/steciana.022.001. 